\title{
An Interactive White6oard Activities-6ased Program to Enhance EFL primary learners' Writing skills and Motivation.
}

\author{
Walaa Adel Abdel Salam Mohamed, Prof. Aly Abdul- \\ Samea Qoura, Ass.Prof.Dr. Mervat Saleh El Hadidy \\ Mansoura University, Faculty of Education, Department of \\ Curriculum \& Instruction
}

\section{ABSTRACT}

The present study aimed at investigating the effect of
using Interactive white board activities based
program (IWB) on improving primary stage pupils' writing skills and their motivation. The targeted writing sub-skills were (Content-vocabulary - grammar-organization - Mechanics of writing). The study adopted the quasi-experimental design using sixty six ${ }^{\text {th }}$ year primary stage pupils to be the study participants who were divided into two groups: an Experimental group received the IWB treatment and a Control group received the traditional method. Instruments designed and used in the study were à writing skills questionnaire, a pre-post writing test, an interactive whiteboard activities check list, and a writing motivation scale. The Experimental treatment was conducted during the second semester in the academic year 2016/2017. Results showed that there were statistically significant differences between the Experimental and control groups on both instruments (EFL writing test and motivation scale) in favor of the Experimental group. In addition, there were statistically significant differences between pre- and post-levels of the Experimental group on both instruments in favor of the post level. These results indicated that the IWB led to developing pupils' EFL writing skills and motivation in English language.

Key words: EFL writing skills, Motivation, and Interactive whiteboard (IWB).

\section{Introduction}

One of the biggest challenges teachers face in the classroom has to do with writing. Weakness in writing skills affect learners' academic level negatively .The purpose of teaching writing as one of the basic language skills is not only to express feeling, thoughts and beliefs but to facilitate learners' learning, their 
daily communication such as (sending an email, writing a paragraph or a friendly letter), socialization, and the development of academic career; so writing is among the most effective tools of communication (Temur, 2004;Rogers, \& Graham, 2008). Although writing is of ample influence for learners both at school and out of school, teaching, evaluating and monitoring of writing skill is supposed to be a domain ignored in the education system and not given enough consideration in classrooms. This indicates that the cognitive, affective and psychomotor skills that present writing success are not fully gained and that there is a lack of awareness about the writing process. (Baştuğ \& Alsaleem, 2014).

Mahran (2000) considered the writing skill as a process of delivering ideas through written texts or translating what is on mind to produce written language.

In describing writing, Olshtain (2001) concluded that it is the process of documenting experiences and thoughts, a basic communication skill, a communicative social activity, a fundamental tool for the study of all other subjects, and a means to further learning, thinking, and discovery. It encourages a creative flow that can help learners use their imaginations, explore possibilities and solve problems .It is a vehicle for language practice which reinforces the grammatical structures, and helps our pupils to learn vocabulary.

Sokolik (2003) concluded that writing is a mental, a major competence and a combination of process and product, which involved synthesizing ideas, thinking about how to express them freely, and organizing them into sentences or paragraphs that will be obvious to the reader. According to Sweeny (2010) "writing had taken on new dimension and played an important role in the way the pupils socialize, share information, and structure their communication" (p. 121). Polkinghorne (2013: 4 ) noted that with writing, pupils could "express, impress, influence, describe, create, report, illustrate, organize, develop thoughts and ideas, put emotion into words, and find answers". 


\section{Motivation}

Smith, Higgins, Wall and Miller (2005) noted that the pupils "zest for learning is enhanced by the element of surprise that IWB can bring to a lesson as it leaves learners wondering what will happen next" (p. 95). Pupils were given the opportunity to physically move objects around on the board. IWB contributed to make lessons "more enjoyable and fun," which in turn may increase their motivation. It provides directed learning ; learners take control of their own learning and are actively engaged in the learning process, where teachers are the facilitators of learning, not the leader. Teachers overlook the leader role and help pupils to lead their learning and construct their own meaning. (p. 107).

Smith, et al (2005) explained that the use of IWB increases motivation because "pupils enjoy interacting physically with the board, manipulating text and images"; thereby it provides more opportunities for interaction and discussion (p. 94).

Walker, (2005) concluded that pupils have been found to be more motivated in classes with IWB because the integration of the device into the classes created more varieties in the class activities.

According to Polkinghorne (2013) motivating young pupils may be difficult through regular methods. To help learners become life-long writers, teachers can use new strategies, techniques, activities, differentiated instructions and programs to help promote writing. Pupils writing is impacted by visually seeing the writing and manipulating items accordingly. Pupils enjoy the games, applications, and website activities, through teaching them how they could compose writing in a fun way, incorporating writing samples and modeling effective writing. Thus, IWB may be an effective tool for teaching writing skills.

\section{Interactive white board (IWB)}

The rapid development of technology has not only opened up new opportunities for learning but also changed the way of teaching and learning English language. Among the new available technologies, the Interactive Whiteboard (IWB) that attracted 
attention in education. IWB is one of the technological means which came into existence in the 1990s. It is a powerful instructional tool that allows computer images to be displayed onto a board using an electronic pen and a digital projector. IWB is a technology which combines the benefits of all teaching aids like the chalkboard, whiteboard, video, overhead projector, CD player and computer in one. It is a flexible tool in the classroom supporting interactivity and collaboration, allowing the integration of multimedia content and resources. [British Educational Communications and Technology Agency, (BECTA, 2015)].

Using IWB technology is an effective way for teachers to bring in rich resources from the internet and enhance pupils understanding of topics, vocabulary development, motivation, cooperation and participation, provide more effective, dynamic and attractive presentations, oral and written language skills. Elements can be dragged, clicked and copied and the teacher can handwrite notes, which can be transformed into text and saved. [The Turkish Online Journal of Educational Technology (TOJET, 2014)].

IWB allows educators to create notebook files on specific topics or written texts, save and revisit past charts, graphic organizers, maps, diagrams, pupil work, curricular materials, dictionaries, drawings, video clips, sound tracks, movies, games and songs used in teaching. IWB brings variety into the class, helps teachers to arrange the classes in ways that address the needs of their learners with different learning styles such as visual, auditory and kinesthetic, and provides learners with many opportunities to get up, share, describe work, move, and interact. (Moony, 2011).

Soares (2010) explained that the IWB helps enhance pupils' autonomy in the classroom, the use of the board encourages collaboration among them and interaction. So, IWB may be a key to increasing learner's motivation to learn. Bannister (2010) noted that there are unlimited tools and techniques the IWB offers, such as pen tools, drag and drop, matching, text tools, rub 
and layering, grouping, handwriting recognition, timers, screen capture, spotlight, blind, animation, recorder, fill tools, subject tools, duplicating, and transparency. (P.12-17). Miller \& Glover (2009) stated that the use of IWB could possibly be "the most significant change in the classroom learning environment in the past decade" (p.221).

Walker (2005) pointed out that IWB works in conjunction with other technologies, so its use allows teachers to reach a number of resources in a short time. It takes learning to a whole new dimension, beyond teacher-centered classes to studentcentered classes utilizing sight, sound, and touch. It moves learners from being one-dimensional thinkers to well-rounded critical thinkers who have a repertoire of experiences. IWB is used for brainstorming sessions, digital storytelling, training learners in keyboarding or imparting computer skills. It helps them to create e-folios and work samples, advance creation of lessons at school or home. IWB offers a range of activities which may not leave pupils passive. Pupils are interested in what is happening on the screen and they want to participate and become part of it.

Therefore, the purpose of this study was to investigate the effect of using IWB on improving six ${ }^{\text {th }}$ grade primary stage writing skills and enhancing their motivation. Accordingly a proposed writing program, based on IWB activities designed to improve some sub skills of writing (content - organization word choice - grammar - mechanics of writing). The proposed program composed of three units. [These include planned features such as, creating a lesson template; saving a lesson; building a library of gallery created items using notebook software activities-based program ; using planned visual links to source material such as Scholastic story starters and Spelling City websites ; incorporating Anime Studio program for creating digital dialogues and Kidspiration graphic program ; including dynamism-manipulation and animation in lessons; effective use of interactive automation ; benefitting from tools of accuracy; using tools of emphasis; timeliness-- keeping lessons current; 
using listing in group activities; editability /transformability/multimodality in lesson format; and providing alternative forms of feedback].

\section{Review of literature}

A number of researches had been done on investigating the relationship between IWB activities and language learning in addition to motivation and writing improvement.

Many studies mentioned that most school pupils face challenges in their writing in English; for example, Harris, Graham, Mason \& Saddler (2002), Tang (2006) , Dessoff (2008) , Abdel Rahem (2011), AlSaleem (2014); and AbdelSamad (2016) proved that writing needs improvement in primary schools.

\section{IWB and language learning}

A number of studies had been carried out to evaluate, discuss or measure the value of IWB in teaching and learning. Levy (2002) gathered opinions of some primary school pupils about integrating the Interactive whiteboard in classrooms, and asserted the effect of IWB on teaching and learning. The pupils listed benefits such as; easier understanding of subject matter, higher concentration, improved participation and motivation, more effective presentation of content, personal and social skills development, effective interaction between peers, virtual learning environment (VLE) integration ,use of games, effective retention and review, aiding memory, and provoking of thoughts and ideas.

Armstrong, Barnes, Sutherland, Curran, Mills \&Thompson (2005) stated that IWB is associated with Socio-cultural theory which claimed that all human action is mediated by tools. IWB can increase interactivity by making use of the different ways of manipulating the applications running on the screen. (p.457). Swan, Schenker \& Kratcoski (2008) reported that the purpose of their research was to investigate the impact of using Interactive whiteboard on English language lessons. The study examined learners' achievement test scores in the third through eighth grades and compared scores between learners whose teachers 
apply IWB activities in instruction and those whose teachers did not. Results showed higher performance among learners in the IWB group, with learners in the $4^{\text {th }}$ and $5^{\text {th }}$ grades showing the greatest advantage of IWB instruction.

Stipe (2011) concluded that IWB helped create a constructivist learning environment by allowing the learners to learn through interactive lessons. Learners actively engage in the learning process through writing, discussion, applying, analysis, synthesis and self-assessment, rather than passively absorbing instruction. They interact with each other through conversation about how a problem is solved or what phases are needed to complete the task on an IWB activity, brings the entire class together, focuses their attention and provides group interaction.

Ltd (2012) believed that learning process became more effective and productive since the IWB helped visualizing and contextualizing the subject's content. Primary pupils perceived how representative and retainable the vivid and colored visuals were unlike the traditional board. The visual display of information on IWB is one reason for facilitated learning and retention. The results indicated that pupils were positive and motivated about instruction with IWB. IWB appealed to both intrinsically and extrinsically motivated learners, this includes: High level of interaction - learners enjoy interacting physically with IWB, manipulating text, image, matching, dragging and dropping objects, keeping the class on task and raising selfesteem.( Cited in AlFaki , 2014).

\section{IWB and writing skills.}

Today research suggests that the effective use of technology provides a collaborative, productive and interactive environment that improves the writing process and supports the social constructivism of learners (Hewett, 2000 and Jonassen, 2005).Writing is a necessity that serves as an indicator of academic achievement. Writing skills can be classified into (1) higher-level writing skills, which include planning, organizing, editing, revising and drafting, and (2) lower-level writing skills, which include handwriting, grammar, punctuation, 
capitalization, vocabulary, and spelling. Pupils who have not acquired good writing skills cannot make full use of writing to support, construct and control their own learning. (Graham and Harris, 2003).

Macaro (2003) illustrated the impact of using computers on enhancing writing skills. The researcher conducted a comparison between interactive writing via computer with traditional writing. The computer group outperformed the other group on grammar points and writing tasks as a result of being motivated than the other one. According to the research of Loschert (2004), IWB provided a setting where learners are collaborating together and manipulating text and ideas with a hands-on activities. As the IWB contains colored vivid pens, highlighting tools, graphic organizer tools, and various fonts and presentation programs that give the learners the opportunity to create their own writing.

Yang \& Chung (2005) claimed that elementary pupils' writing performance is enhanced by an interactive online writing system that includes peer review, topical prompts and comments from readers.Their study indicated that the frequency of writing on the computer network is important factor to improve pupils' writing skills. It supported developing their independence to write, freeing the teacher to work with pupils in small groups or independently.

In investigating the effect of using computer games on improving learners writing skills, Warren (2006) examined the impact of a multi-user virtual environment on teacher instructional time. The results of this study showed that the treatment condition led to a reduction in teacher time, growth in the numbers of voluntary learner writing activities, improvements in standardized achievement scores on questions that require writing tasks and learner's engagement with the learning environment. According to Neimeyet (2006) using technology improved learners' writing skills and the learners would be able to complete writing tasks faster.

Wagner (2008) investigated the effect of graphic organizer on enhancing some writing skills. The purpose of this study was 
to determine if the incorporation of a computer graphic program (Kidspiration), might enhance learners' writing skills. The treatment took place in a fourth grade language arts classroom during writing periods. The data for this four week study indicated that using the Kidspiration computer program increased learner organizational skills in writing.

Gomez (2009) argued that writing is a communicative and social competence. Therefore, pupils can develop their writing through interaction, as it involves not just expression of one's own ideas and thoughts, but understanding of those of the others. This view is also supported by Vygotsky (1978) who believed that children are active scientists whose cognitive ability is increased through interaction. Vygotsky identified an instructional area that he titled the Zone of Proximal Development 'ZPD'. It is the zone that links the gap between what is known and what can be known. This is the place where true learning occurs and where teachers should direct their teaching. Hence, developing writing skills through social constructivism may enhance them. Cited in Lin (2009). Sometimes learners had trouble getting their thoughts on paper. Using a social approach to learning may help teachers to support their learners in writing. (Read, 2010).

In his study, Lin (2009) examined how computer-mediated communication affects learners' writing processes and writing performance through interacting, changing information, communicating, constructing knowledge, and collaborating with peers. Cited in (AbdelRahem, 2010). A study by Grimes (2010) focused on the effects of a one-to-one laptop program on learners' achievement in writing skills. Research was conducted from two middle schools and two elementary schools. The study concluded that learners who use a one-to-one laptop program have improved writing test scores. Cited in (Polkinghorne 2013).

A study by Moony (2010: 76 ) was conducted to focus on whether the IWB impacted the development of learners' writing. The data collection occurred through classroom observations, teacher surveys and teacher interviews. Results showed that 
learners were motivated to write with the board and their writing has improved since using the IWB, as it was "a great tool for showing writing samples, modeling effective writing" and an interactive resource to promote writing development of skills . The agency of BECTA (2015) stated that the "IWB facilitates learners participation through the ability to interact with materials on the board" (p. 1).So the IWB may be used with developing writing skills in an independent manner.

Therefore, this study aimed to investigate how teachers can effectively incorporate the interactive whiteboard into EFL classroom with the purpose of improving learners writing skills and increasing their motivation, using several IWB instructional activities that have a positive effect on pupils learning include: Highlighting, coloring, Flipping back and forth to review previous content, providing reviewing techniques, using pictures for discussion and brainstorming, interactive writing, shared reading, peer-teaching, and collaborative problem solving, hide and reveal , drag and drop, and matching items activities, finding hidden part of a picture with spotlight or screen-shade , Capturing screenshots from web pages ,Correcting mistakes in the materials, and Playing games

\section{The pilot study:}

The researchers conducted a pilot study to measure sixth grade primary stage pupil's current level of EFL writing skills and motivation. A selected sample was taken from Khalid Altokhy primay school to check the pupils' writing performance on the first term exam, 2015. The sample included sixty $(n=60)$ participants.The following table shows the mean score and the percentage of writing section on the writing test.

Table (1) Pupils' Mean score in the pilot study

\begin{tabular}{|c|c|c|c|}
\hline Writing sub-skills & $\mathrm{N}$ & Mean Score & Std. Deviation \\
\hline Content & 60 & 1.54 & 0.92 \\
\hline Organization & 60 & 1.25 & 0.96 \\
\hline Grammar & 60 & 3.78 & 1.56 \\
\hline Vocabulary (word choice) & 60 & 4.18 & 1.91 \\
\hline Mechanics of writing & 60 & 2.40 & 1.22 \\
\hline Total & 60 & 13.15 & 6.57 \\
\hline
\end{tabular}

Table (1) Pupils' Mean score, SD and percentage on the writing Test $(\mathrm{N}=60)$ 
Table (1) shows the total score of the writing test was 13.15 that is considered an indication of the pupils' low level in writing skills (Content - Vocabulary - grammar - organizationmechanics of writing). The highest mean score was 4.18 in word choice sub-skill while the lowest mean was 1.25 in the organization. This level may be due to a number of variables that include the lack of training in using appropriate writing learning activities.

\section{Statement of the problem}

Based on the previous literature, related studies, the researchers experience, and the results of the pilot study, the problem of the study was stated as follows:

The sixth grade EFL primary stage pupils have some difficulties in some writing skills (content - vocabulary grammar - organization- mechanics of writing) that should be mastered at their level, this leads to a lack of high motivation towards writing. Thus, there is a need for some IWB activities to improve EFL writing skills and motivation of those pupils.

\section{Questions of the study:}

The research questions were discussed as follows:

1. What is the current level of $6^{\text {th }}$ grade primary stage pupils in EFL writing skills?

2. What are the IWB activities and applications that will be used to enhance writing skills and motivation of $6^{\text {th }}$ grade primary school pupils?

3. What is the effect of an IWB activities-based program on enhancing the writing skills of the $6^{\text {th }}$ grade primary stage pupils?

4. What is the effect of an IWB activities-based program on enhancing motivation of the $6^{\text {th }}$ grade primary stage pupils?

\section{Purpose:}

The purpose of this study was:

1. To identify the components of some IWB Activities-based program that might enhance learners' writing skills and motivation. 
2. To investigate the effect of an IWB Activities-based program on improving 6th grade primary school pupils' writing skills and motivation.

\section{Hypotheses:}

The current study will verify the following hypotheses:

1. There is a statistically significant difference at the .05 level in the mean score of the post administration of the writing test between the Experimental (IWB) group and the control (non-IWB) group in favor of the Experimental group.

2. There is a statistically significant difference at the .05 level between the mean score of the Experimental group pre and post administration of the writing test in favor of the post administration.

3. There is a statistically significant difference at the .05 level in the mean score of the post administration of the motivation scale between the Experimental (IWB) group and control (non-IWB) group in favor of the Experimental group.

4. There is a statistically significant difference at the .05 level between the mean score of the Experimental group pre-post administrations of the writing motivation scale in favor of the post administration.

\section{Delimitations:}

The study was delimited to the following circumstances:

1. $6^{\text {th }}$ grade primary school pupils from Al shahid Khalid Altokhy primarySchool.

2. Some writing skills stated by Ministry of Education for $6^{\text {th }}$ grade primary stage (content -vocabulary- grammar organization - mechanics of writing).

\section{Methodology:}

The research design: 
To investigate the impact of using Interactive whiteboard activities-based program on improving pupils' writing skills and motivation, the researcher adopted the quasi-experimental research design including two groups of 30 sixth - year primary pupils of two classes, randomly selected from Al shahid Khalid Altokhy primarySchool. The two classes are randomly assigned to two groups; Experimental and control one. The proposed program will be used in teaching the experimental group while the regular method will be used with the control.

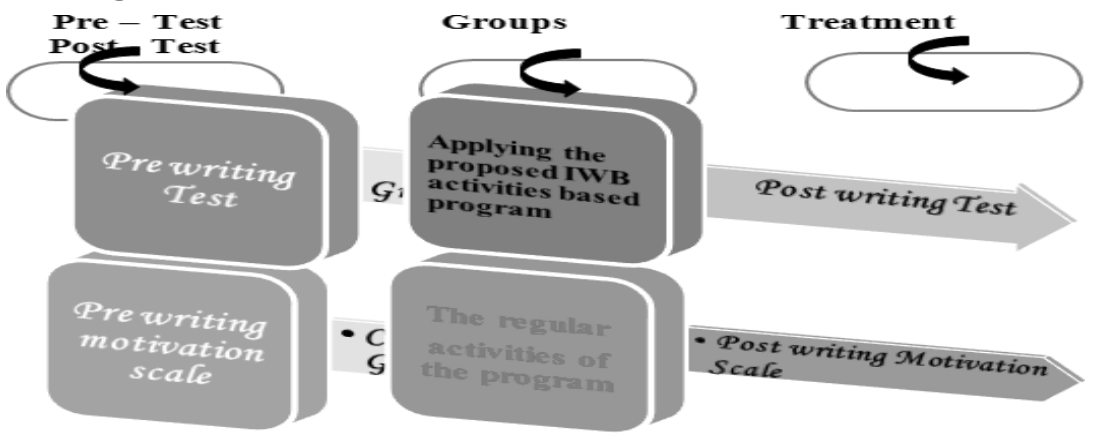

Figure (1): The quasi-experimental design of the study Instruments:

The following instruments were designed and used:

1. A writing skills questionnaire to determine the most important writing skills necessary for EFL primary school pupils, and consequently determine the skills to be included in both the test and the program.

2. A Pre-post writing skills test was used to measure the writing skills of the participants and designed by the researchers .

3. An Interactive Whiteboard activities checklist to determine the most suitable IWB activities necessary for developing sixth year primary pupils' writing skill .

4. A pre-post writing motivation scale to determine the level of pupils' motivation to writing before and after the administration of the proposed program.

5. A Rubric for assessing EFL $6^{\text {th }}$ primary stage pupils writing skills. 


\section{Results and discussions}

Results were statistically analyzed in terms of the hypotheses. They were discussed in the light of the theoretical background and related studies. Results were reported as follows:

\section{Testing the first hypothesis:}

The first hypothesis stated that "There is a statistically significant difference at the .05 level in the mean score of the post administration of the writing test between the Experimental (IWB) group and the control (non-IWB) group in favor of the Experimental group".

Table (2) reports the results of the t-test in comparing the pupils' mean score in the writing sub-skills post writing test and the overall performance for the experimental and control group.

Table (2)a comparison between the mean score of the Experimental and control groups on the post administration of the writing test

\begin{tabular}{|c|c|c|c|c|c|c|}
\hline \multirow[t]{2}{*}{ Skill } & \multirow[t]{2}{*}{ Group } & \multirow[t]{2}{*}{$\mathbf{N}$} & \multirow[t]{2}{*}{ Mean } & \multirow{2}{*}{$\begin{array}{c}\text { Std. } \\
\text { Deviation }\end{array}$} & \multicolumn{2}{|c|}{$\begin{array}{c}\begin{array}{c}\text { Paired T- } \\
\text { test }\end{array} \\
\end{array}$} \\
\hline & & & & & $T$ & Sig \\
\hline \multirow{2}{*}{ Content } & Experimental & 30 & 2.73 & 1.08 & \multirow[t]{2}{*}{5.32} & \multirow{2}{*}{0.00} \\
\hline & Control & 30 & 1.46 & 0.83 & & \\
\hline \multirow{2}{*}{ Organization } & Experimental & 30 & 2.50 & 1.14 & \multirow{2}{*}{4.57} & \multirow{2}{*}{0.00} \\
\hline & Control & 30 & 1.30 & 0.88 & & \\
\hline \multirow{2}{*}{ Word choice } & Experimental & 30 & 7.46 & 1.98 & \multirow{2}{*}{7.13} & \multirow{2}{*}{0.00} \\
\hline & Control & 30 & 4.20 & 1.77 & & \\
\hline \multirow{2}{*}{ Grammar } & Experimental & 30 & 9.00 & 2.29 & \multirow{2}{*}{10.3} & \multirow{2}{*}{0.00} \\
\hline & Control & 30 & 3.76 & 1.57 & & \\
\hline \multirow{2}{*}{ Mechanics } & Experimental & 30 & 6.46 & 1.87 & \multirow{2}{*}{9.68} & \multirow{2}{*}{0.00} \\
\hline & Control & 30 & 2.63 & 1.09 & & \\
\hline \multirow{2}{*}{ Total Score } & Experimental & 30 & 28.16 & 6.67 & \multirow{2}{*}{9.86} & \multirow{2}{*}{0.00} \\
\hline & Control & 30 & 13.16 & 4.97 & & \\
\hline
\end{tabular}

Results in table (2) indicate that the mean score of the pupils in each writing sub-skill in the experimental post-test was higher than that of pupils' in the control group .Moreover, the table shows that the pupils mean score in the overall postwriting test in the experimental group was (28.16) compared to the control group overall score in the post-test (13.16).

The paired t-test results indicate that the difference between the mean score of the pupils in the post-writing test was 
statistically significant at the 0.5 level in favor of the post administration of the IWB activities program for the Experimental group.

\section{Testing the second hypothesis:}

The second hypothesis stated that " There is a statistically significant difference at the .05 level between the mean score of the Experimental group pre and post administration of the writing test in favor of the post administration".

To test the second hypothesis, the t-test for paired samples was used to compare the difference between the mean score of the experimental group pupils in the writing test before and after administering the study intervention (using IWB activities basedprogram) to determine the effect of the study intervention on their writing sub-skills. Table (6) presents the results.

Table (3)comparison between the experimental group pre and post administration of the writing test

\begin{tabular}{|c|c|c|c|c|c|c|}
\hline \multirow{2}{*}{ Skill } & \multirow{2}{*}{ Group } & \multirow{2}{*}{$\mathbf{N}$} & \multirow{2}{*}{ Mean } & \multirow{2}{*}{ Std.Deviation } & \multicolumn{2}{|c|}{ Paired T-test } \\
\hline & & & & & $\mathbf{T}$ & Sig \\
\hline \multirow{2}{*}{ Content } & Pre & \multirow[b]{2}{*}{30} & 1.57 & 0.93 & \multirow{2}{*}{6.06} & \multirow{2}{*}{0.00} \\
\hline & Post & & 2.73 & 0.83 & & \\
\hline \multirow{2}{*}{ Organization } & Pre & \multirow[b]{2}{*}{30} & 1.47 & 0.86 & \multirow{2}{*}{3.78} & \multirow{2}{*}{0.001} \\
\hline & Post & & 2.50 & 1.13 & & \\
\hline \multirow{2}{*}{ Word choice } & Pre & \multirow[b]{2}{*}{30} & 4.20 & 1.91 & \multirow{2}{*}{6.99} & \multirow{2}{*}{0.00} \\
\hline & Post & & 7.47 & 1.77 & & \\
\hline \multirow{2}{*}{ Grammar } & Pre & \multirow[b]{2}{*}{30} & 3.80 & 1.58 & \multirow{2}{*}{10.2} & \multirow{2}{*}{0.00} \\
\hline & Post & & 9.00 & 2.28 & & \\
\hline \multirow{2}{*}{ Mechanics } & Pre & \multirow[b]{2}{*}{30} & 2.73 & 0.91 & \multirow{2}{*}{9.18} & \multirow{2}{*}{0.00} \\
\hline & Post & & 6.47 & 1.88 & & \\
\hline \multirow{2}{*}{ Total Score } & Pre & \multirow[b]{2}{*}{30} & 13.77 & 4.48 & \multirow{2}{*}{9.69} & \multirow{2}{*}{0.00} \\
\hline & Post & & 28.17 & 6.67 & & \\
\hline
\end{tabular}

Results in Table (3) show that the t- value is highly significant at 0.01 level, which indicates that participants' mean score of each writing sub-skill in the post-test increased (2.73, $2.50,7.47,9.00$, and 6.47$)$. These results could be attributed to the implementation of the IWB activities program which was effective in improving each writing sub-skill.

A closer look to the total score, table (3) reveals that the pupils' mean score in the overall pre-writing test in the 
experimental group was (13.77) compared to the mean score in the post-writing test which was (28.17). The improvement in the mean score of the experimental group in the post-test indicates that the participants' performance in the overall writing has been developed due to the IWB activities program.

\section{The Effect size of the proposed activities:}

First, eta square ( $\eta 2$ ) was estimated to calculate the effect size of the proposed program on the pupils' writing skills. Eta square ( $\eta 2$ ) was estimated after calculating the t-value. The following table illustrates the effect size of the proposed program on the experimental group pupils' writing skills.

Table (4) the effect size of using IWB activities on the Experimental group's writing sub-skills' development.

\begin{tabular}{|c|c|c|c|c|}
\hline Skill & df & T & Eta square $\left(\eta^{2}\right)$ & $\begin{array}{c}\text { Level of effect } \\
\text { size }\end{array}$ \\
\hline Grammar & 29 & 10.27 & 0.64 & High \\
\hline $\begin{array}{c}\text { Mechanics of } \\
\text { writing }\end{array}$ & 29 & 9.18 & 0.59 & High \\
\hline Word choice & 29 & 6.99 & 0.45 & High \\
\hline Content & 29 & 6.06 & 0.38 & High \\
\hline Organization & 29 & 3.78 & 0.16 & High \\
\hline Total & 29 & 9.69 & 0.61 & High \\
\hline
\end{tabular}

Results in table(4) illustrate the eta square for each writing sub-skills and the total of these sub-skills. The effect size values are $(0.64,0.59,0.45,0.38,0.16)$. It is obvious that all of these values exceeded 0.14 level. This indicate respectively a high effect size for all the writing sub-skills of the experimental treatment. The results of the t-test for paired samples indicate that there were statistically significant differences at level $<0.001$ between the mean scores of the experimental group on the pre posttest administration and that the effect size was high. So, each sub-skill of the pupils' writing skills has been improved after adminstrating the program.

\section{Conclusion}

This study concluded that using IWB activities based program can enhance EFL primary stage pupils' writing skills and that to writing to learn not learning to write should be the core of teaching writing as a part of language learning for primary stage. 


\section{Pedagogical implications}

Writing skills via IWB could be emphasized in teaching writing to help pupils in the primary stage acquire and practice the writing skills as early as possible.

The objectives of teaching English language should focus on writing skills beyond the mechanics level, emphasize writing as a process, concentrate on pupils' motivation to write and various strategies to activate their taste for writing.

Teachers need to work collaboratively with colleagues and experts and exchange experiences, ideas, activities, materials, lesson plans and resources in order to save treasured time which can be dedicated to teaching writing skills.

Teacher should be selective, innovative and creative in choosing adequate ; meaningful; motivating ; multiple ; engaging; communicative materials and topics that make writing experience, tasks and activities more realistic and relevant.

IWB needs to be used attentively and teachers should keep in mind a back-up plan if something wrong happened. Thus depending on one resource, specifically a technology-based one, may lead to challenging and difficult situations for teachers.

The Ministry of education could identify an efficient team of teachers to give ongoing support and help their colleagues through conducting small demo sessions during the summer holiday, and establish a database of subjects, instructional materials and resources in order to ease the load on teachers in adapting interactive lessons.

\section{Suggestions for Further Research.}

In the light of the results retrieved in the present study, a number of elements can be suggested for future research:

First, more action researches and case studies might be conducted on the integration of the IWB as a means of teaching and improving listening, speaking, reading skills and pupils' attitude towards English.

More action researches and case studies could conducted on raising teacher's awareness of pupils' motivation loss and the 
need to incorporate various strategies to stimulate their taste for writing.

Second, more researches might be conducted to investigate the effect of using some IWB activities such as (category sort activity- spinner wheel- image and text arrange- Multiple choice - Note reveal- blue pairs- sentences arrange - pull tab- Vortex sort- Teal word guess- word biz -Dice key word - Key word match- random text tool- Random word chooser - Text splitter word generator) on enhancing pupil's vocabulary and grammar.

Third, schools should implement specific training programs and ongoing support to equip both pupils and teachers to deal with the interactive features of the IWB.

\section{References}

AbdelRahem, A.A. (2011).The Effect of Using Computer Edutainment on Developing $2^{\text {nd }}$ Primary Graders' Writing Skills. A thesis submitted in requirement for The Master Degree in Education: Ain Shams University.

Abd El Samad, S .R . (2016) Internet based Linguistic Intelligence Activities for EFL Primary School Pupils' Writing Skills. Mansoura University.

Al-faki, I .M. (2014).Difficulties Facing Teachers in Using Interactive Whiteboard in Their Classes. American International Journal of Social Science ,3(2).English Language Institute King Abdul Aziz University -KSA Wadi El-Neel University -Sudan.

Al-Saleem, B.I.A (2013). The interactive whiteboard in English as a foreign language (EFL) classroom. European Scientific Journal.8, 3, pp.126-134.

Armstrong, V., Barnes, S., Sutherland, R., Curran, S., Mills, S. \& Thompson, I. (2005). Collaborative research methodology for Investigating teaching and learning: the use of interactive Whiteboard technology, Educational Review, 57(4), (Pp.456-457).

Bannister, D. (2010).Guidelines for Effective School/Classroom Use of Interactive Whiteboards. The EuSCRIBE Project. Brussels: uropean School net.Pp.12-17, Wolvernhapton University. 
Baştuğ, M. (2014). Effects of Primary School Fourth-Grade Students' Attitude, Disposition and Writer's Block on Writing Success. Education and Science Vol 40 (2015) No $18073-88$

BECTA, (2015).What research says about interactive whiteboards. /retrieved October 2015, from http://becta .org.com /corporate /publication/documents/Research Whiteboards.

Betcher, C. and Lee. M. (2009). The Interactive Whiteboard Revolution: Teacher with IWB.Acer Press, Australia. National Library of Australia Cataloguing-in- Publication data.

Bettsworth, B. (2010). Using interactive whiteboards to teach grammar In the MFL Classroom: A learner's perspective. In Thomas, M \& Schmid, E. (Eds), Interactive Whiteboards for education: Theory, research and practice (pp. 238- 250), USA.

Dessoff, A. (2008). Righting the writing process. District Administration. (p.51). In Moony, M. (2011). Interactive Whiteboards: Impact on Fifth- Grade Writing Skills. Education and Human Development Master's Theses. The College at Brockport, dmooney@ leroycsd. Org.

Gomez, T. (2009). Developing Emergent Literacy Skills in Kindergarten Students Using Pre-A Book. Published doctoral dissertation, Walden University.

Graham, S., \& Harris, K.R. (2003). Students with learning disabilities and the process of writing: A meta-analysis of SRSD studies. In Swanson, H \& Grham, S (Eds) Handbook of learning disabilities (Pp. 383-402).New York: Guilford Press.

Grimes, D., Hernandez, D., Suhr, K., \& Warschauer, M., (2010). Laptops and fourth - grade literacy: assisting the jump over the fourth - grade slump .The Journal of Technology, Learning, and Assessment, 9 (5), Pp. 1-46. In Polkinghorne, M. (2013). Top Research - based writing strategies for motivating early elementary authors. Submitted to Northern Michiagn University.

Hewett, B.L. (2000). Characteristics of interactive oral and computer mediated Peer Group talk and its influence on revision. Computers and Composition. 
Higgins, S., Beauchamp, G., \& Miller, D. (2007). Reviewing the literature on Whiteboards. REVIEW ARTICLE: Learning, Media and Technology, 32(3), pp213-225. A University of Durham, UK; bSwansea Institute of Higher Education, UK; cKeele University, $U K$.

Keshtal, a. s. \&Harb, I.I. (2013). The effectiveness of a blended learning program on developing Palestinian tenth graders' English Writing skills. Education Journal 2(6) (PP. 208221).

Levy, P. (2002). Interactive whiteboards in teaching and learning in two Sheffield Schools. A developmental study Sheffield: Sheffield University.

Lin, S.M. (2009). How computer-mediated communication affects ELL students' Writing processes and writing performance. Published doctoral dissertation, the University of Oklahoma.

Loschert, K. (2004). Bye bye blackboards. National Education Association.Pp 30-3 1.In oony, M. (2011). Interactive Whiteboards: Impact on Fifth- Grade Writing Skills. Education and Human Development Master's Theses. The College at Brockport, dmooney @leroycsd.org.

Ltd, E. (2012). Honeymoon with IWBs: A qualitative insight in Primary students' views on instruction with interactive whiteboard: journal homepage: www.elsevier. com/locate/compedu.

Macaro, E (2003).Teaching and learning a second language Continuum, (1st edition). A guide to recent research and its application .Portsmouth.

Miller, D. \& Glover, D. (2009) .Interactive whiteboard in the web 2.0 classroom. (P.221).Scholarly Article.

Mooney, D, M. (2011).Interactive Whiteboards: Impact on FifthGrade Writing Skills. Education and Human Development Master's Theses. The College at Brockport, dmooney@leroycsd.org.

Neimeyet, S, A. (2006). An Examination of the Effects of Computer- Assisted Educational Games On student Achievement. Published master's thesis, University of Houston Clear Lake. 
Olshtain, E. (2001). Functional tasks for mastering the mechanics of writing and going Just beyond. http://www.slideserve.com/tass/ functional-tasks- formastering-the Mechanics-of-writing-and-going-justbeyond.

Polkinghorne, M. M. (2013). Top research - based writing strategies for motivating Early elementary stage. Northern Michigan University In partial fulfillment of The requirements for the degree of MASTER OF ARTS.

Read, S. (2010). A model for scaffolding writing instruction: IMSCI. Reading Teacher, 64(1), 47-52.In Mooney, D, M. (2011).Interactive Whiteboards: Impact on Fifth- Grade Writing Skills.

Rogers, L. A., \& Graham, S. (2008). A meta-analysis of single subject design writing intervention Research. Journal of Educational Psychology, 100(4), 879-906.in Education and Science Vol 40 (2017) No 180 73-88.

SMART. (2004) interactive whiteboard and learning A review of classroom studies and Research literature. SMART Technologies Inc.

SMART. (2006). Interactive whiteboards and learning: improving Student learning Outcomes and streamlining lesson planning. SMART Technologies Inc.

Smith, H. J., Higgins, S., Wall, K \& Miller, J. (2005). Interactive whiteboards: boon or bandwagon? A critical review of the literature". Journal of Computer Assisted Learning 21, (pp.94-107).

Soares, A. D. (2010). IWBs as support for technology-related projects in EFL education in Brazil. In M. Thomas \& E. C. Schmid (Eds.), Interactive 80 whiteboard for education: Theory, research and practice (pp. 238-250). United States.

Sokolik, M. (2003). Writing. Practical English Language Teaching. In D. Nunan (Ed.). New York: McGraw-Hill, (pp.87-108).

Stipe, A. (2011). Interactive whiteboards: A study of student engagement and academic achievement Curriculum and Instruction LaGrange, Georgia. (pp. 11-25).

Swan, K., Schenker, J. \& Kratcoski, A. (2008). The effects of the use of Interactive Whiteboards on student achievement. Research Center for Educational Technology Kent State University, United States. 
Sweeney, S. M. (20 1 0). Writing for the instant messaging and text messaging generation: Using new literacies to support writing instruction. Journal of Adolescent and Adult Literacy, 54 (2), (p.1 2 1).

Tang, X. (2006). Principles in Teaching Process. Writing in a Learner-Centered Classroom, 3 (2), East China Jiao Tong University.

Temur, T. (2004). Effects of Primary School Fourth-Grade Students' Attitude, Disposition and Writer's Block on Writing Success. Education and Science Vol 40 (2017) No180 73-88.

TOJET. (2014) .Teachers and students perception of Interactive Whiteboard in the English as a foreign language classroom. The Turkish Journal of Educational Technology, 13 (3) .Department of Foreign Language, Faculty of Education, Hacettepe University, Ankara 06800, Turkey hoz@hacettepe,edu.tr.

Vygotsky, L. S. (1978). Mind in society: The development of higher psychological processes. Massachusetts: Harvard University Press.

Walker, R.J. (2005).Teaching and learning with interactive Whiteboards in Leask, M and Pachler, N. (2013). (Eds.), learning to teach Using ICT in The secondary School (pp. 86-100). Routledge, London.

Wagner, E. (2008). Running Head: Improving writing with graphic organizers. Published master's thesis, Graduate Program Caldwel College.

Warren, S, J. (2006). The impact of a multi-user virtual environment on teacher instructional time, voluntary student writing practice, and student writing achievement. Published doctoral dissertation, Indiana University, United States.

Wikia (2016). Interactive White boards. Retrieved (Jan, 2016) from http:// School Computing. Wikia. Com/wiki/ Interactive White boards.

Yang, J. C. \& Chung, I. L. (2005). Web-based interactive writing environment: Development and evaluation. Educational Technology \& Society, 8(2), (pp.214- 229). 
